\title{
MITES (ACARI) PHORETIC ON SIX-TOOTHED SPRUCE BARK BEETLE, PITYOGENES CHALCOGRAPHUS LINNAEUS (COLEOPTERA: CURCULIONIDAE: SCOLYTINAE), IN WESTERN SIBERIA, RUSSIA
}

\author{
Alexander A. Khaustov ${ }^{1 *}$, Vyacheslav A. Trach² and Andrei N. Bobylev ${ }^{1}$
}

\author{
${ }^{1}$ Tyumen State University, Tyumen, Russia \\ ${ }^{2}$ I. I. Mechnikov Odessa National University, Odessa, Ukraine \\ *corresponding author; e-mail: alex1973khaustov@gmail.com
}

\begin{abstract}
In total 11 species of mites were revealed to be phoretic on Pityogenes chalcographus L. in a spruce-pine forest near Tyumen, Western Siberia, Russia: Uroobovella ipidis (Vitzthum, 1923) (Urodinychidae), Trichouropoda polytricha (Vitzthum, 1923) (Trematuridae), Pleuronectocelaeno barbara Athias-Henriot, 1959 (Celaenopsidae), Schizosthetus sp. (Parasitidae), Dendrolaelaps (Ipidodendrolaelaps) quadrisetosimilis Hirschmann, 1960 (Digamasellidae), Proctolaelaps fiseri Samsinak, 1960 (Melicharidae), Siculobata (Paraleius) leontonycha (Berlese, 1910) (Scheloribatidae), Histiostoma piceae Scheucher, 1957 (Histiostomatidae), Pyemotes dryas (Vitzthum, 1923) (Pyemotidae), Heterotarsonemus coleopterorum (Schaarschmidt, 1959), and Tarsonemus bistridentati Magowski and Khaustov, 2006 (Tarsonemidae). The hyperphoresy by deutonymphs of Histiostoma picea and Trichouropoda polytricha on other phoretic mites on bark beetles are recorded.
\end{abstract}

KEY WORDS: Acarina, phoresy, hyperphoresy, bark beetle, SEM photographs, spruce, pine.

DOI: 10.21684/0132-8077-2016-24-2-137-151

\section{INTRODUCTION}

Many mites (Acari) are known as associates of various bark beetles (Coleoptera: Curculionidae, Scolytinae) (Lindquist 1970). They include predators that prey on bark beetle eggs and their larvae, nematodes and other mites, which inhabit bark beetle galleries as well as myco- and saprophagous mites and parasitoids of bark beetle eggs and other beetle instars (Hofstetter et al. 2015). Most mites inhabiting bark beetles galleries utilize adult beetles for phoresy (Lindquist 1970). The communities of mites associated with particular bark beetles are best studied only for several economically important pests, such as Dendroctonus frontalis in North and Central America (Moser, Roton 1971; Kinn 1976; Stephen, Kinn 1980), Ips typographus, I. sexdentatus, Pytyocteines spp, Scolytus multistriatus, S. pygmaeus in Europe (Lieutier 1978; Moser, Bogenschütz 1984; Moser et al. 1989, 2005; Perneck et al. 2008, 2012; Čejka, Holuša 2014; Gwiazdowicz et al. 2011, 2012; Vrabec et al. 2012; Moraza et al. 2013; Penttinen et al. 2013), Ips typographus japonicus in Japan (Moser et al. 1997).

The six-toothed spruce bark beetle, Pityogenes chalcographus L. (Coleoptera: Scolytinae) is a widely distributed pest in Eurasia, infesting mainly spruce (Picea spp.) as well as other conifer species such as Pinus spp., Abies spp., Larix spp. (Avtzis et al. 2010). The phoretic mites on P. chalcographus are poorly studied. In spite of 25 mite species recorded as associates of this species in Poland (Kielczewski et al. 1983), only a few are known to be phoretic. Kiełczewski et al. (1983) recorded the phoresy of female Pyemotes dryas on P. chalcographus. Zach et al. (2016) reported about the phoresy of deutonymphs of Trichouropoda polytricha on P. chalcographus in Slovakia.

During this study of mites associated with bark beetles in Western Siberia, 11 species of mites were recorded as phoretic on the Pityogenes chalcographus beetles. The aim of this paper is to provide information on mites phoretic on $P$. chalcographus in Western Siberia.

\section{MATERIAL AND METHODS}

Branches and twigs of the Siberian spruce (Picea obovata) and Scots pine, (Pinus sylvestris) containing overwintering six-toothed spruce bark beetles, Pityogenes chalcographus Linnaeus, 1761, were taken from several localities in mixed forest of Scots pine and Siberian spruce in the vicinity of settlement Uspenka, Tyumen Province, Tyumen District, Russia $57^{\circ} 04^{\prime} \mathrm{N}, 65^{\circ} 04^{\prime} \mathrm{E}, 22$ April-5 May 2016. The samples were placed into plastic bags and kept at room temperature in the laboratory. Beetles leaving the branches and twigs were collected using an aspirator and placed into vials containing $96 \%$ ethanol. Thereafter, alcohol sediments from the vials were inspected for phoretic mites. Galleries of Pityogenes chalcographus were also examined in some samples. For these purposes, bark with galleries of the beetles was removed and examined with a stereomicroscope Discovery V8, Carl Zeiss. For the SEM microscopy, live beetles were placed into a refrigerator 
and frozen at a temperature of $-25^{\circ} \mathrm{C}$; after that, beetles with phoretic mites were separated and scanned without dusting with the aid of a JEOLJSM-6510LV SEM microscope. A total of 331 beetle individuals were examined to determine the approximate number of phoretic mites. Mites from the alcohol sediments were mounted in Hoyer's medium for the light-microscopy. The morphology of mites was studied using the Carl Zeiss Axio Imager, A2 microscope with DIC and phase contrast objectives. The studied material is deposited in the mite collection of the Tyumen State University Museum of Zoology, Tyumen, Russia.

\section{RESULTS}

\section{Order: Mesostigmata Cohort: Antennophorina Family: Celaenopsidae}

Pleuronectocelaeno barbara Athias-Henriot, 1959

(Figs. 1A-D, 4E)

This predatory species is known to be distributed in Algeria (Athias-Henriot 1959), North America (Kinn 1968; Moser, Roton 1971), Sweden (Sellnick 1951; Kinn 1991; Moser et al. 1989), Denmark, Norway (Kinn 1991), Croatia (Perneck et. al. 2008, 2012), Italy (Plumari 2008), Iran (Ahadiyat et al. 2012) and Russia (Khaustov 1997). It is known as an associate of many bark beetle species: Dendroctonus frontalis, Ips avulsus, I. calligraphus, I. confusus, I. grandicollis, I. crebricollis, I. typographus, Orthotomicus sabinianae (Hofstetter et al. 2015), Pityogenes sp. (Kinn 1991), Ips acuminatus (Sellnick 1951), Orthotomicus erosus (Ahadiyat et al. 2012), Pityocteines curvidens (Perneck 2008, 2012), Crypturgus cinereus (Plumari 2008), Tomicus minor, Hylurgops palliatus, Pityogenes bistridentatus, Taphrorychus bicolor (Khaustov 1997).

In our study, we documented a phoretic association of males and females of P. barbara with P. chalcographus (Figs. 1C, D). Males and females of $P$. barbara did not attach to specific sites on the bark beetles and freely moved around the beetle body. This is a first record of $P$. barbara in the Asian part of Russia.

Material examined. Eight females, 7 males, Tyumen Province, Tyumen District, vicinity of settlement Uspenka, $57^{\circ} 04^{\prime} \mathrm{N}, 65^{\circ} 04^{\prime} \mathrm{E}, 22$ April-5 May 2016, on Pityogenes chalcographus, coll. A. A. Khaustov.

\section{Cohort Gamasina \\ Family Parasitidae}

Schizosthetus sp.

(Figs. 1E, F)

Three species of the genus Schizosthetus AthiasHenriot, 1982 have been described, Sch. lyriformis (McGraw and Farrier 1969) from North and Central Americas, Sch. vicarius Athias-Henriot, 1982 from North America and Sch. simulatrix Athias-Henriot, 1982 from the Canary Islands and Portugal (AthiasHenriot 1982). In North and Central America Sch. lyriformis is associated with lps avulsus, I. calligraphus, I. confusus, I. grandicollis, Dendroctonus brevicomis, $D$. frontalis, $D$. simplex, $D$. valens, Onthotomicus latidens. Sch. lyriformis preying on eggs and larvae of bark beetles (Hofstetter et al. 2009). Al-Atawi et al. (2002) redescribed this species for all instars. Kaluz et al. (2003) redescribed Sch. simulatrix based on material from Slovakia, Germany, Sweden, and France. The authors also suggested that a mite identified as Parasitus (Vulgarogamasus) lyriformis (McGraw and Farrier 1969) from Northern Russia (Arkhangelsk) (Tikhomirov 1977) and South Siberia (Altai Republic) (Davydova and Nikolsky 1986) is, in fact, Sch. simulatrix, because, after studying specimens of Vulgarogamasus sp., previously reported as associates of bark beetles Ips sexdentatus in France (Lieutier 1978), Ips typographus in Germany (Moser and Bogenschütz 1984) and Sweden (Moser et al. 1989), they identified them as Sch. simulatrix (Kaluz et al. 2003). Plumari (2008) recorded nymphs and adults of Sch. simulatrix from Italy in the galleries of bark beetles Crypturgus cribellus, Crypturgus mediterraneus, Xyleborinus saxesenii, and weevil beetles Brachytemnus porcatus, Dryophthorus corticalis. It was also recorded from Croatia from Pityocteines curvidens (Perneck et al. 2008, 2012) and Latvia from Hylurgops palliatus (Salmane and Telnov 2009). Sch. vicarius Athias-Henriot, 1982 is known only from the type series from moss and soil on the trunk of Pseudotsuga menziesii.

In our study, we documented the phoresy of deutonymphs of $S c h$. sp. on P. chalcographus (Figs. 1E, F). Only two species of the genus Schizosthetus are known from deutonymphs (Sch. lyriformis and Sch. simulatrix), our specimens differ from both species by the length of dorsal setae, and correct determination could be possible after a study of adult mites. Deutonymphs of Schizosthetus had no preference for specific sites for their phoretic attachment on the bark beetle and freely moved 


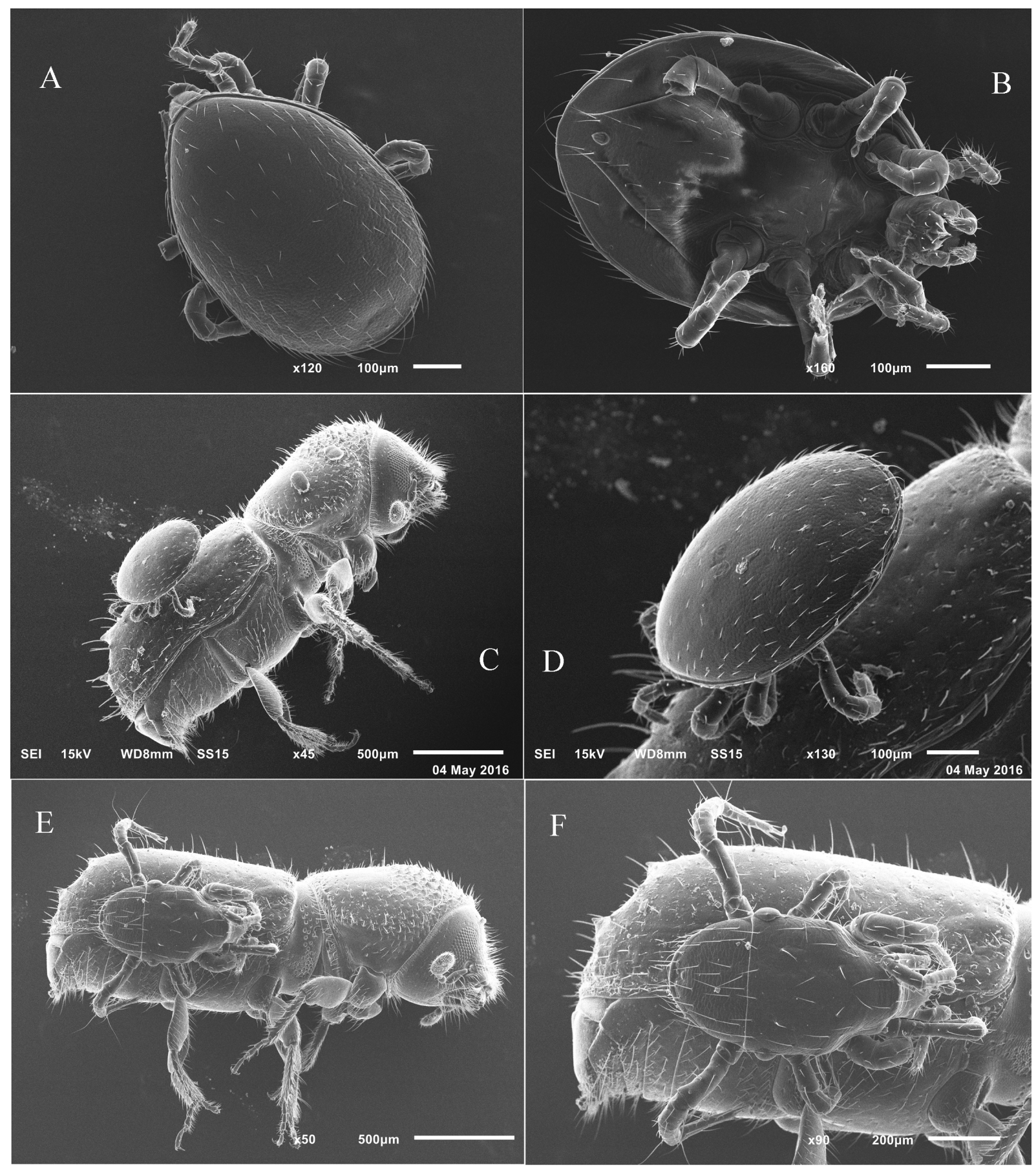

Fig 1. SEM photographs. A-B —Pleuronectocelaeno barbara Athias-Hentiot, 1959: female, A-dorsal view, B — ventral view; C-general view of male of P. barbara and females of Tarsonemus bistridentati on Pityogenes chalcographus, D-dorsolateral view of male of P. barbara, E-F-phoresy of deutonymph of Schizosthetus sp. on Pityogenes chalcographus.

around the beetle body. Previously, Schizosthetus had never been reported as an associate of Pityogenes beetles.

Material examined. Six deutonymphs, Tyumen Province, Tyumen District, vicinity of settlement Uspenka, $57^{\circ} 04^{\prime} \mathrm{N}, 65^{\circ} 04^{\prime} \mathrm{E}, 22$ April-5 May 2016, on Pityogenes chalcographus, coll. A. A. Khaustov.

\section{Family Melicharidae}

\section{Proctolaelaps fiseri Samšinak, 1960}

(Figs. 2A-C)

This predatory species is widely distributed in the Holarctic, where it is associated with various subcortical beetles, especially bark beetles (Hofstetter et al. 2015). 


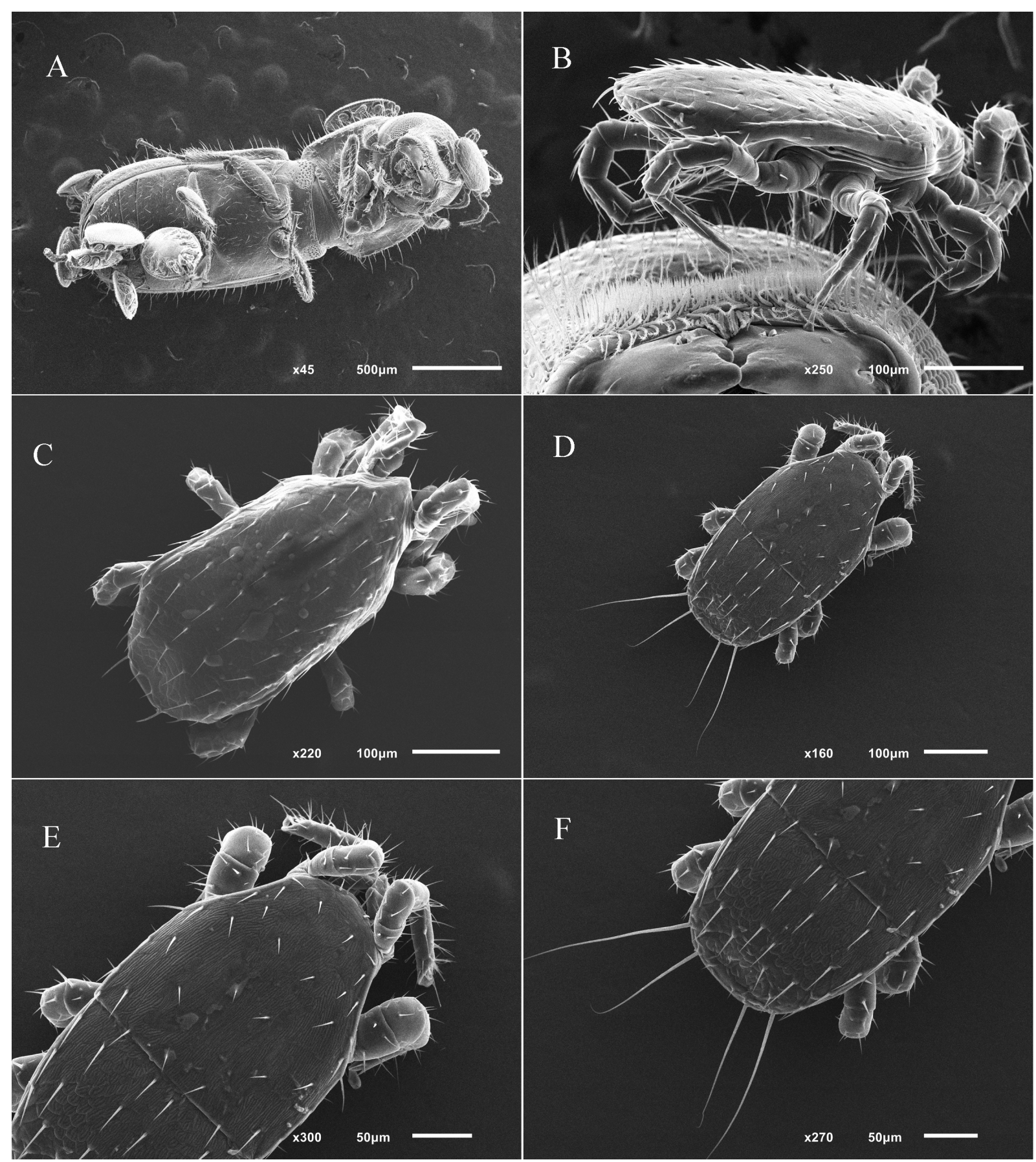

Fig. 2. SEM photographs. A-general view of mites phoretic on Pityogenes chalcographus, female of Proctolaelaps fiseri Samšinak, 1960 (on the head) and deutonymphs of Trichouropoda polytricha (Vitzthum, 1923), B-female of Proctolaelaps fiseri on the head of the beetle, C-dorsal view of Proctolaelaps fiseri; deutonymph of Dendrolaelaps (Ipidodendrolaelaps) quadrisetosimilis Hirschmann, 1960: C-dorsal view of the body, D-anterior part of the body dorsally, E-posterior part of the body dorsally.

This species was described from within the former Czechoslovakia on Ips typographus under bark. Westerboer (1963) recorded P. fiseri from Germany as an associate of several species of bark beetles (Ips typographus, Hylurgops palliatus, Dryocoetes autographus, Tomicus piniperda, Pityokteines curvidens, Ernoporicus fagi) and the cerambycid beetle Spondylis buprestoides. Lindquist and Hunter (1965) reported P. fiseri in the USA from the galleries of Ips calligraphus.

It was also recorded from Latvia from a dead pine with Hylurgops palliatus (Salmane 2007).

Gwiazdowicz (2008) also reported it from Poland as an associate of 38 species of bark beetles. 
Furthermore, it was recorded from European Russia from the galleries of Ips typographus (Maslov, Matusevich 2008) and from Western Siberia (Davydova, Nikolsky 1986).

In our study, we documented the phoresy of females of $P$. fiseri on $P$. chalcographus (Figs. 2A, B) for the first time. Females of $P$. fiseri have no specific sites for phoresy on bark beetles and freely move around the beetle body. Previously $P$. fiseri has never been reported as an associate of Pityogenes beetles.

Material examined. Nine females, Tyumen Province, Tyumen District, vicinity of settlement Uspenka, $57^{\circ} 04^{\prime} \mathrm{N}, 65^{\circ} 04^{\prime} \mathrm{E}, 22$ April-5 May 2016, on Pityogenes chalcographus, coll. A. A. Khaustov.

\section{Family Digamasellidae}

\section{Dendrolaelaps (Ipidodendrolaelaps) quadrisetosimilis Hirschmann, 1960}

(Figs. 2D-F)

This predatory species is known to be located in both Europe and North America (Hirschmann and Wisniewski 1982; Moser and Roton 1971; Knee et al. 2013). D. quadrisetosimilis was described from Germany from the stump of a spruce tree. Moser and Roton (1971) reported it from the USA from the galleries of Dendroctonus frontalis. D. quadrisetosimilis was also recorded from Canada on Orthotomicus caelatus (Knee et al. 2013). In Poland D. quadrisetosimilis was found in the galleries of 13 species of bark beetles (Gwiazdowicz 2008).

In our study we found only two deutonymphs in alcohol sediments. Previously D. quadrisetosimilis has never been reported as an associate of Pityogenes beetles. This is the first record of $D$. quadrisetosimilis in Russia.

Material examined: Two deutonymphs, Tyumen Province, Tyumen District, vicinity of settlement Uspenka, $57^{\circ} 04^{\prime} \mathrm{N}, 65^{\circ} 04^{\prime} \mathrm{E}, 22$ April-5 May 2016, on Pityogenes chalcographus, coll. A. A. Khaustov.

\section{Cohort Uropodina Family Urodinychidae}

\section{Uroobovella ipidis (Vitzthum, 1923)}

(Figs. 3A-E)

This species is known from Austria, Germany, Poland, Croatia, Russia, Lebanon, Slovakia (Mašan 2001), Sweden (Moser et al. 1989), the Czech Republic (Čejka and Holuša 2014), and
Spain (Fernández et al. 2012). Deutonymphs of this species are phoretic on various bark beetles: Ips typographus (Moser and Bogenschütz 1984; Moser et al. 1989; Feketesová 2011, Gwiazdivicz et al. 2012; Vrabec et al. 2012; Čejka and Holuša 2014), Ips sexdentatus (Fernández et al. 2012), Hylastes cunicularius (Kršlak et al. 2010), Pityocteines curvidens, $P$. spinidens, $P$. worontzowi (Perneck et al. 2008, 2012) and Pityogenes chalcographus (Zach et al. 2016).

In our study, we found only three deutonymphs of this species attached to the elytral declivity and the dorsal thorax of the beetle (Figs. 3A, C, D).

Material examined. Three deutonymphs, Tyumen Province, Tyumen District, vicinity of settlement Uspenka, $57^{\circ} 04^{\prime} \mathrm{N}, 65^{\circ} 04^{\prime} \mathrm{E}, 22$ April-5 May 2016, on Pityogenes chalcographus, coll. A. A. Khaustov.

\section{Family Trematuridae}

\section{Trichouropoda polytricha (Vitzthum, 1923)}

(Figs. 2A, 4)

This species is known from Germany, the Czech Republic, Slovakia, Turkmenustan (Mašan 2001), Sweden (Moser et al. 1989), Austria (Kofler and Schmölzer 2000), Poland (Gwiazdowicz and Gutowski 2012), Slovenia (Moraza et al. 2013), Finland (Penttinen et al. 2013), Spain (Fernández et al. 2012), Switzerland, Turkey, Canada, USA. (Knee et al. 2012), and Mexico (Chaires-Grijalva et al. 2013). Deutonymphs of this species are phoretic on various bark beetles: Ips typographus (Moser and Bogenschütz 1984; Moser et al. 1989; Feketesová 2011, Fernández et al. 2012; Gwiazdivicz et al. 2011, 2012; Knee et al. 2012; Vrabec et al. 2012; Penttinen et al. 2013, Čejka, Holuša 2014), Ips sexdentatus (Fernández et al. 2012), Hylastes cunicularius (Kršlak et al. 2010), Dryocoetes autographus, Hylurgors palliatus, Ips amitinus, I. cembrae, I. hauseri, I. pilifrons utahensis, I. woodi, I. montanus, I. perturbatus, I. hunteri, I. borealis, Pityogenes chalcographus (Knee et al. 2012) and Dendroctonus rhizophagus (ChairesGrijalva et al. 2013).

In our study, T. polytricha was the most abundant species. We collected 420 deutonymphs of this species attached mainly to the posterior part of the abdomen and to the area between the legs (Figs. 4B-D; sometimes mites were attached to elytra and thorax (Fig. 2A). In some cases we recorded up to 11 deutonymphs of $T$. polytricha per one beetle. This is the first record of T. polytricha in Russia. 


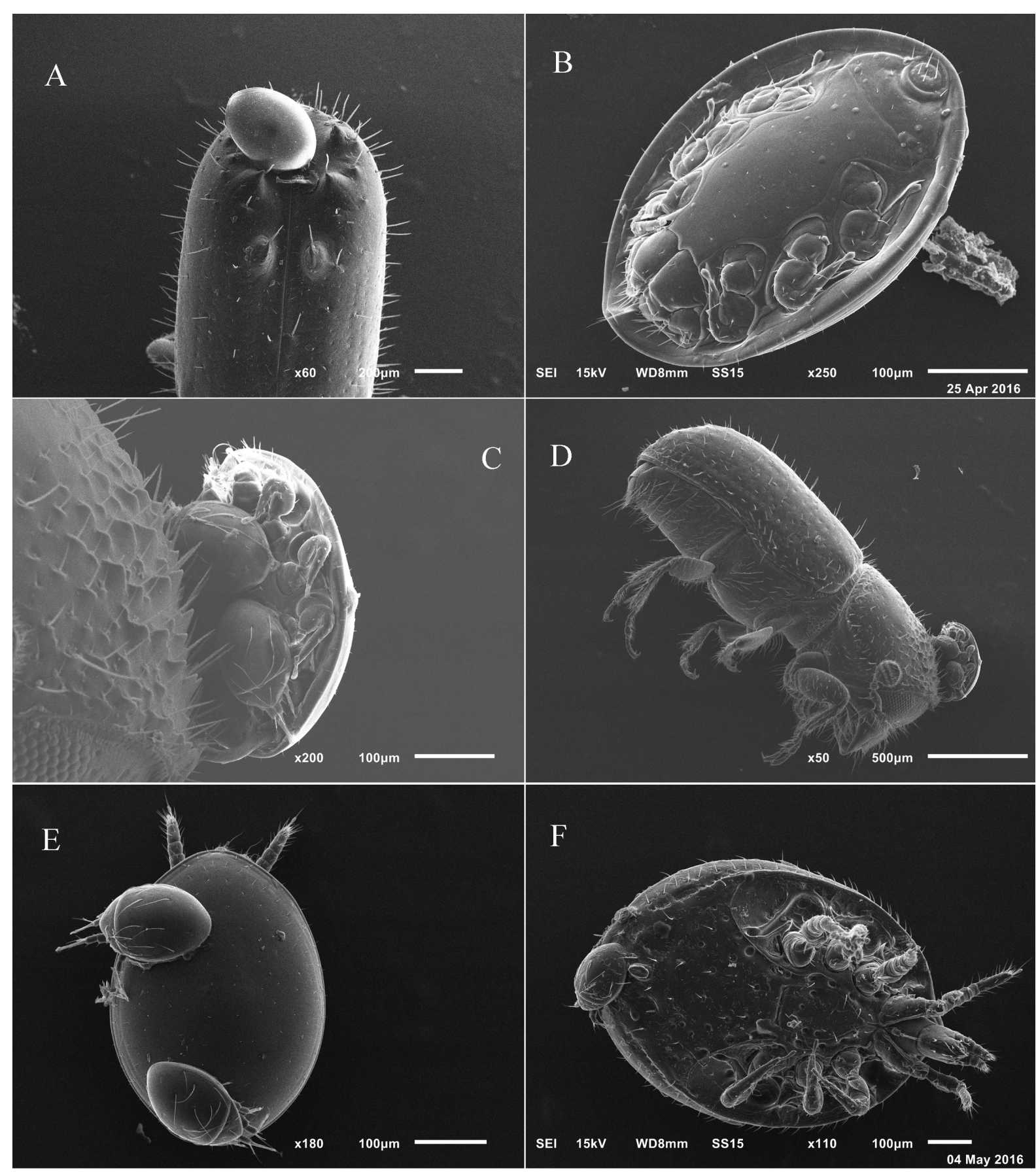

Fig. 3. SEM photographs. A-deutonymph of Uroobovella ipidis (Vitzthum, 1923) on elytral declivity of the male of Pityogenes chalcographus, B-Uroobovella ipidis, ventral view of deutonymphs, C-D - deutonymph of Uroobovella ipidis with hyperphoretic deutonymphs of Histiostoma piceae, E-dorsal view of deutonymph of Uroobovella ipidis with hyperphoretic deutonymphs of Histiostoma piceae, F-female of Trichouropoda sp. with phoretic deutonymph of Histiostoma piceae.

Material examined: Four hundred twenty one deutonymphs, Tyumen Province, Tyumen District, vicinity of settlement Uspenka, $57^{\circ} 04^{\prime} \mathrm{N}, 65^{\circ} 04^{\prime} \mathrm{E}$, 22 April-5 May 2016, on Pityogenes chalcographus, coll. A. A. Khaustov.

\section{Order Sarcoptiformes Suborder Oribatida Family Scheloribatidae}

Siculobata (Paraleius) leontonycha (Berlese, 1910)

(Fig. 5A-D)

Ahadiyat and Akrami (2015) recently reviewed the distribution and the preferred habitats of this 


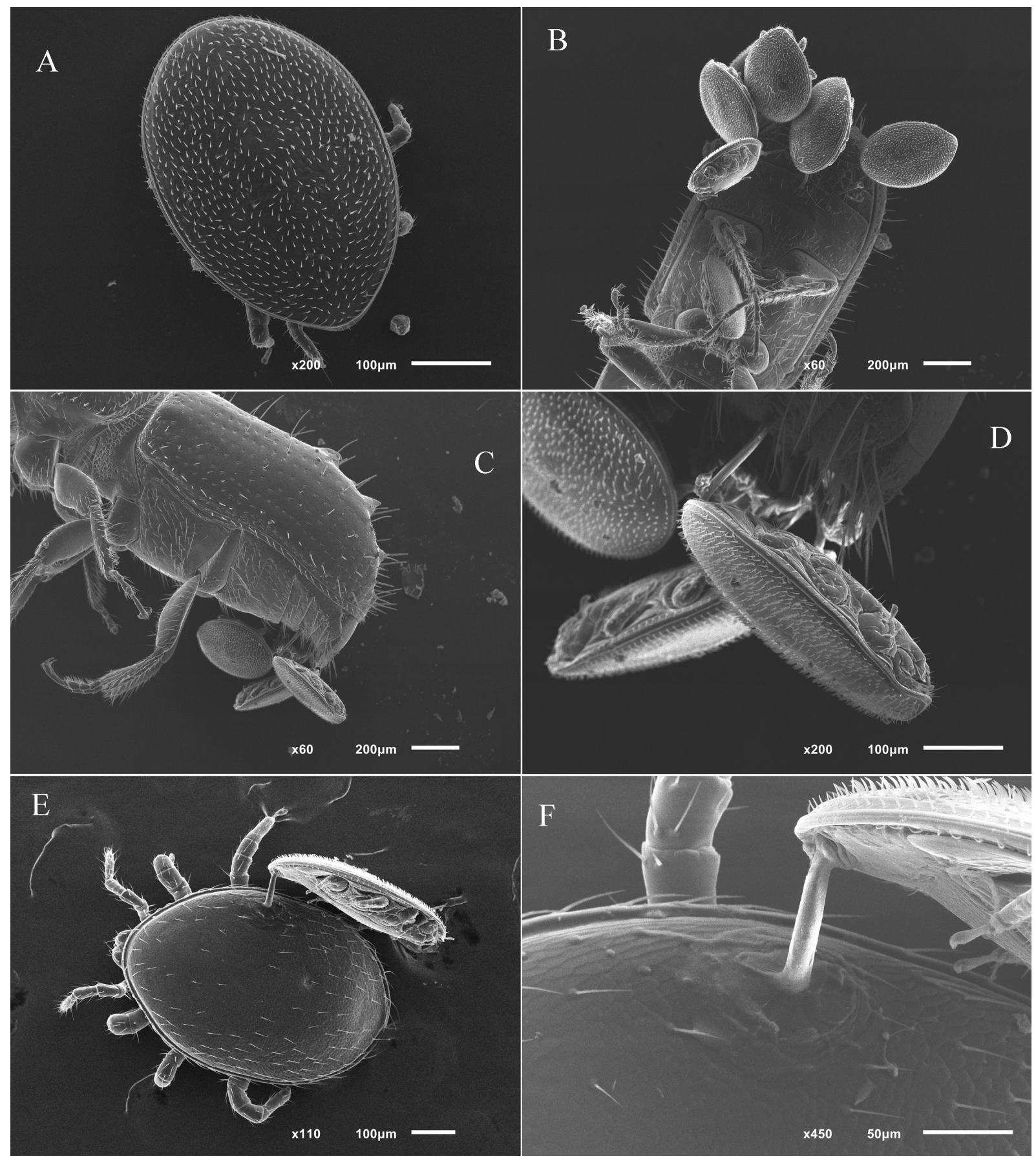

Fig. 4. SEM photographs. A-deutonymph of Trichouropoda polytricha, dorsal view, B-D-deutonymphs of Trichouropoda polytricha on abdomen of Pityogenes chalcographus, E-F-hyperphoresy of deutonymph of Trichouropoda polytricha on female of Pleuronectocelaeno barbara.

species. It is distributed in the Holarctic region and associated with numerous species of bark beetles.

In the galleries of $P$. chalcographus, which sometimes crossed galleries of Ips typographus, Siculobata (Paraleius) leontonycha was one of the most abundant species. Nonetheless, we found only one female in the alcohol sediments. Probably $P$. chalcographus can only be occasionally a phoretic host for $S$. leontonycha.
Material examined. One female, Tyumen Province, Tyumen District, vicinity of settlement Uspenka, $57^{\circ} 04^{\prime} \mathrm{N}, 65^{\circ} 04^{\prime} \mathrm{E}, 22$ April-5 May 2016, on Pityogenes chalcographus, coll. A. A. Khaustov; 25 females, in the galleries of $P$. chalcographus under the bark of Picea obovata, same locality, 22 April 2016, coll. A. A. Khaustov. 


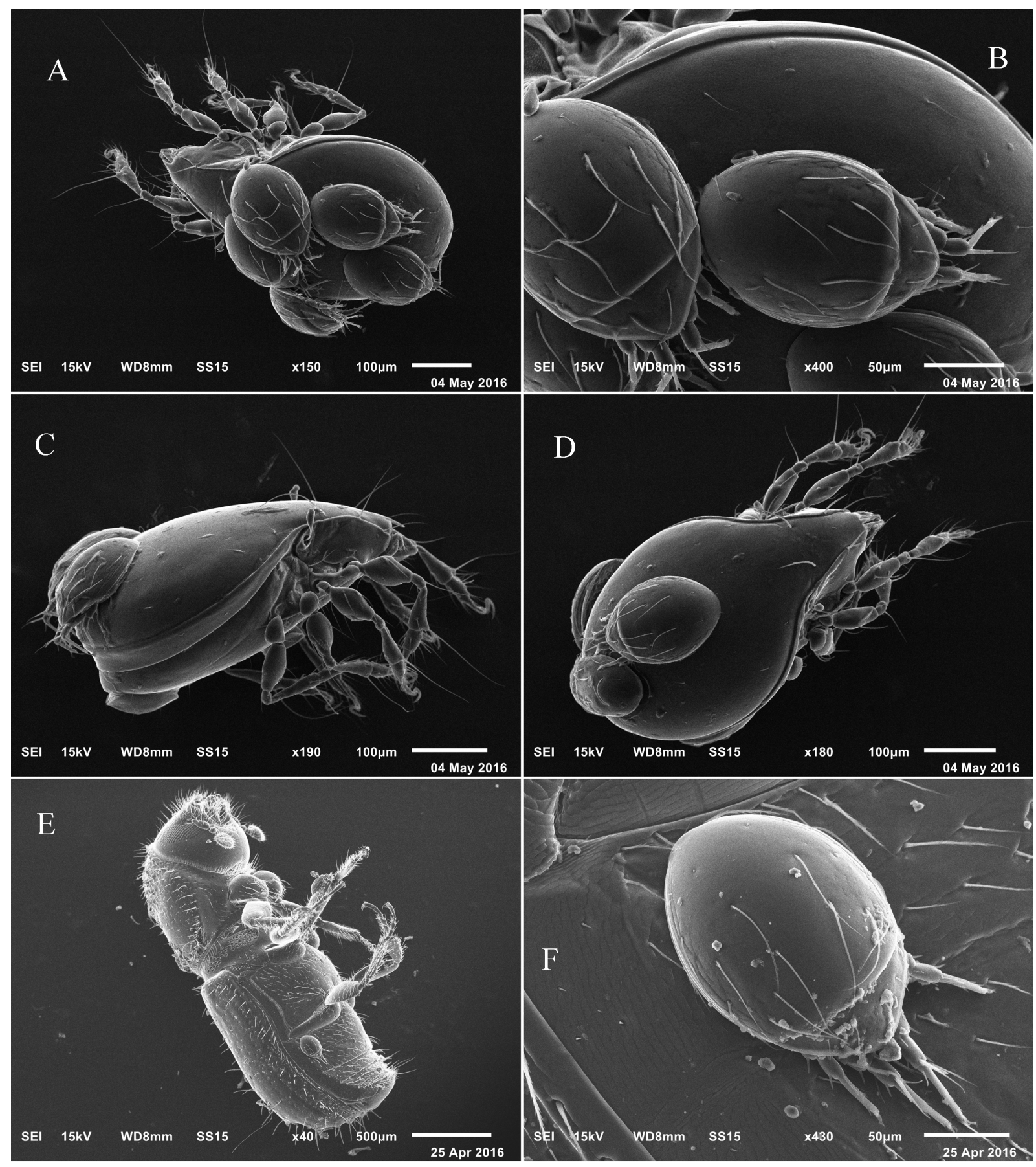

Fig. 5. SEM photographs. A-D-females of Siculobata (Paraleius) leontonycha (Berlese, 1910) with phoretic deutonymphs of Histiostoma piceae, D-E-deutonymph of Histiostoma piceae Scheucher, 1957 on abdomen of Pityogenes chalcographus.

\section{Cohort Astigmatina Family Histiostomatidae}

\section{Histiostoma piceae Scheucher, 1957}

$$
\text { (Figs. 3C-E, 5A-E) }
$$

Histiostoma piceae Scheucher, 1957 was assumed by its describer to be specifically associated with Ips typographus and the tree Picea abies. According to Scheucher's findings, all instars develop inside the galleries of I. typographus. She discovered fresh detritus containing mostly free-living stages, while deutonymphs finally appeared when a detritus was not available any more. She sampled in Regensburg, Höbing (nearby Roth) and the Harz (Germany). One hundred percent of all examined beetles were carrying deutonymphs. Scheucher additionally found deutonymphs of $H$. piceae on Staphylinus sp. Meanwhile, H. piceae was discovered phoreti- 
cally associated with different bark beetles (Pernek et al. 2012). As the species-determination was often performed based only on the deutonymph, these identifications require verifications. For a clear determination, at least deutonymphs and adults need to be available because deutonymphs of the piceaegroup look very similar to each other (Scheucher 1957; Wirth et al. 2016). Wirth et al. (2016) reared H. piceae from deutonymphs attached to the siblingbeetle-species Ips typographus and I. cembrae from Central Croatia.

According to Scheucher (1957), these mites can be reared under laboratory conditions on rotting bran or potato, but mass cultures could not be established. Wirth et al. (2016) confirmed these findings. They additionally discovered that $H$. piceae reared most successfully in presence of the corresponding beetles.

Material examined. Fifteen deutonymphs, Tyumen Province, Tyumen District, vicinity of settlement Uspenka, $57^{\circ} 04^{\prime} \mathrm{N}, 65^{\circ} 04^{\prime} \mathrm{E}, 22$ April-5 May 2016, on Pityogenes chalcographus, coll. A. A. Khaustov; 2 deutonymphs, on deutonymph of Uroobovella ipidis attached to P. chalcographus, same locality, 22 April 2016, coll. S. F. Wirth; 1 male and 1 female in the galleries of P. chalcographus under the bark of Picea obovata, same locality, 22 April 2016, coll. S. F. Wirth; 14 deutonymphs, on females of Siculobata (Paraleius) leontonycha in the galleries of $P$. chalcographus under the bark of Picea obovata, same locality, 22 April 2016, coll. A. A. Khaustov; 2 deutonymphs, same locality and data, on deutonymph of Uroobovella ipidis, coll. A. A. Khaustov; 6 deutonymphs, same locality and data, on females and males of Trichouropoda sp., coll. A. A. Khaustov.

\section{Order: Trombidiformes Suborder: Prostigmata Family: Pyemotidae}

\section{Pyemotes dryas (Vitzthum, 1923)}

(Figs. 6C-E)

This species was first described from Austria from the galleries of the bark beetle Pityogenes bistridentatus (Vitzthum 1923). P. dryas is furthermore reported from the galleries of Polygraphus polygraphus, Pityogenes chalcographus, P. bidentatus, and Ernoporus tiliae in Poland (Kielczewski and Wisniewski 1980; Kielczewski et al. 1983). It was also recorded from Germany and Sweden phoretic on Ips typographus (Moser and Bogenschütz 1984; Moser et al. 1989). Khaustov
(1998) reported $P$. dryas from Crimea from the galleries of Pityogenes bistridentatus and Phloeosinus bicolor. This species was exported from Poland to USA (Moser et al. 1978) as a potential agent for biological control of Dendroctonus frontalis. Moser et al. (1978) studied the biology of $P$. dryas and revealed that it is not phoretic on $D$. frontalis or six other associated beetles.

We collected eight females attached to the area between the coxae of $P$. chalcographus (Figs. $6 \mathrm{C}-\mathrm{E})$. There is usually only one phoretic female per one beetle. In one case, we recorded two females per beetle.

Material examined. Eight females, Tyumen Province, Tyumen District, vicinity of settlement

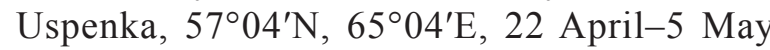
2016, on Pityogenes chalcographus, coll. A. A. Khaustov.

\section{Family Tarsonemidae}

\section{Heterotarsonemus coleopterorum (Schaarschmidt, 1959)}

This species was first described from Germany on Pityogenes bidentatus (Schaarschmidt 1959). It was also recorded from Crimea from the galleries of Pityogenes bistridentatus (Khaustov 2001). An unidentified species of Heterotarsonemus was recorded from Poland (Kielczewski and Wisniewski 1980) from the galleries of Pityogenes chalcographus, P. bidentatus, and Crypturgus pusillus. With a very high probability, it could be conspecific with $\mathrm{H}$. coleopterorum because this species is specifically associated with Pityogenes beetles (Khaustov 2001).

We collected three females attached to the area between the coxae of $P$. chalcographus. There is usually only one phoretic female per one beetle, representing a new record for the Asian part of Russia.

Material examined. Three females, Tyumen Province, Tyumen District, vicinity of settlement Uspenka, $57^{\circ} 04^{\prime} \mathrm{N}, 65^{\circ} 04^{\prime} \mathrm{E}, 22$ April-5 May 2016, on Pityogenes chalcographus, coll. A. A. Khaustov.

\section{Tarsonemus (Schaarschmidtia) bistridentati Magowski and Khaustov, 2006}

(Figs. 1C, 7)

This species was described from Crimea in the galleries of Pityogenes bistridentatus (Magowski and Khaustov 2006). It was also recorded from Poland from the galleries of Pityogenes chalcographus, Polygraphus polygraphus, Crypturgus sp., Ips typographus, Trypodendron lineatum and from 


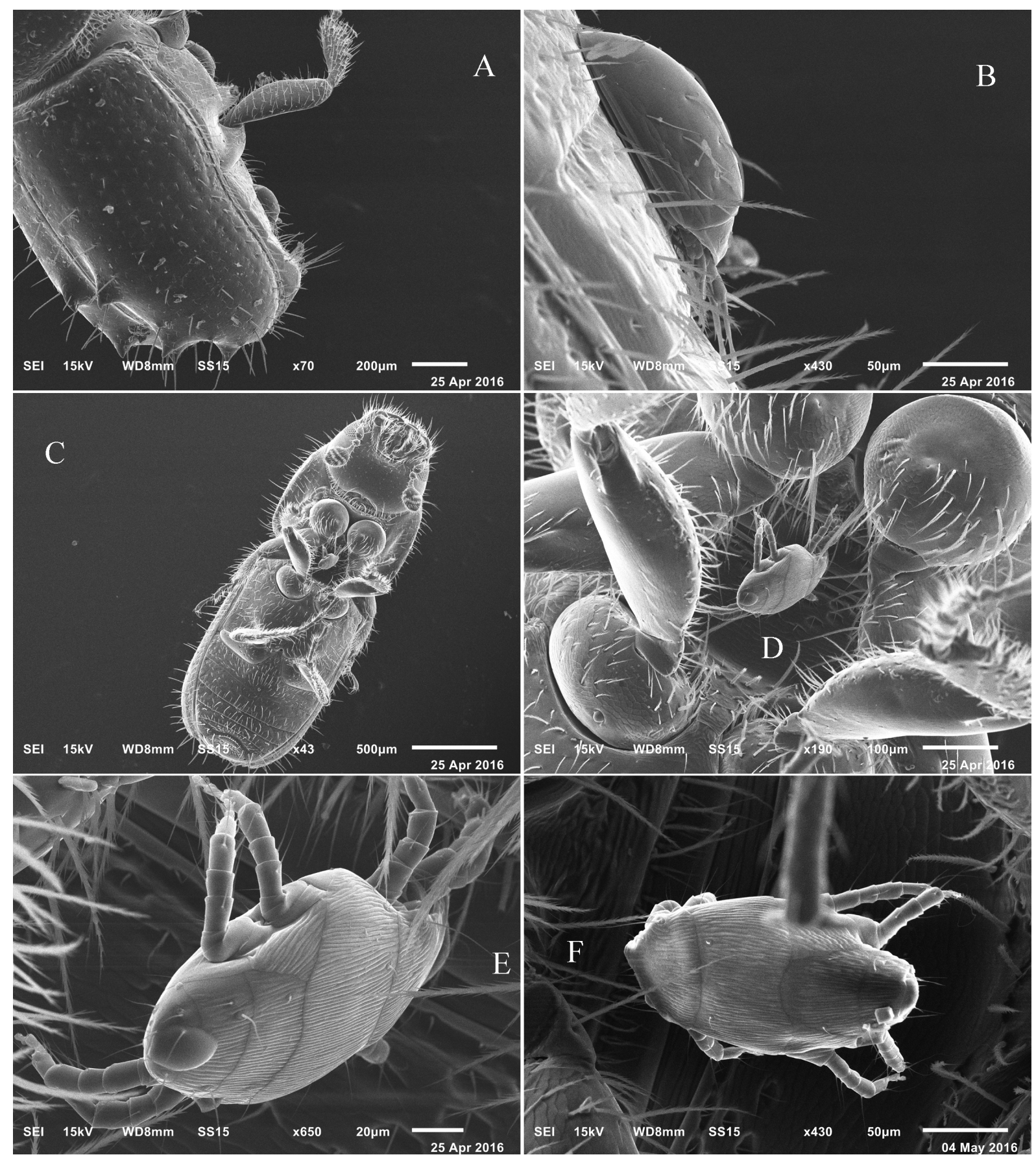

Fig. 6. SEM photographs. A-B-deutonymphs of Histiostoma piceae Scheucher, 1957 on abdomen of Pityogenes chalcographus, C-F-females of Pyemotes dryas (Vitzthum, 1923) between coxae of Pityogenes chalcographus.

Spain and Switzerland phoretic on Ips acuminatus (Magowski 2010).

We collected numerous females attached to the areas between the coxae of $P$. chalcographus (Figs. 7E, F). Nevertheless, some specimens could also attach to other parts of beetle body (Figs. 1C, 7A-D). This marks a new finding for the Asian part of Russia.

Material examined. One hundred sixty eight females, Tyumen Province, Tyumen District, vicinity of settlement Uspenka, $57^{\circ} 04^{\prime} \mathrm{N}, 65^{\circ} 04^{\prime} \mathrm{E}, 22$
April-5 May 2016, on Pityogenes chalcographus, coll. A. A. Khaustov.

\section{Phoresy of mites on Pityogenes chalcographus}

In spite of the relatively low number (331) of collected individuals of Pityogenes chalcographus, we collected 651 individuals of 11 species of mites (Table 1). Two of them, Trichouropoda polytricha (64.66\%) and Tarsonemus bistridentati (25.80\%) 


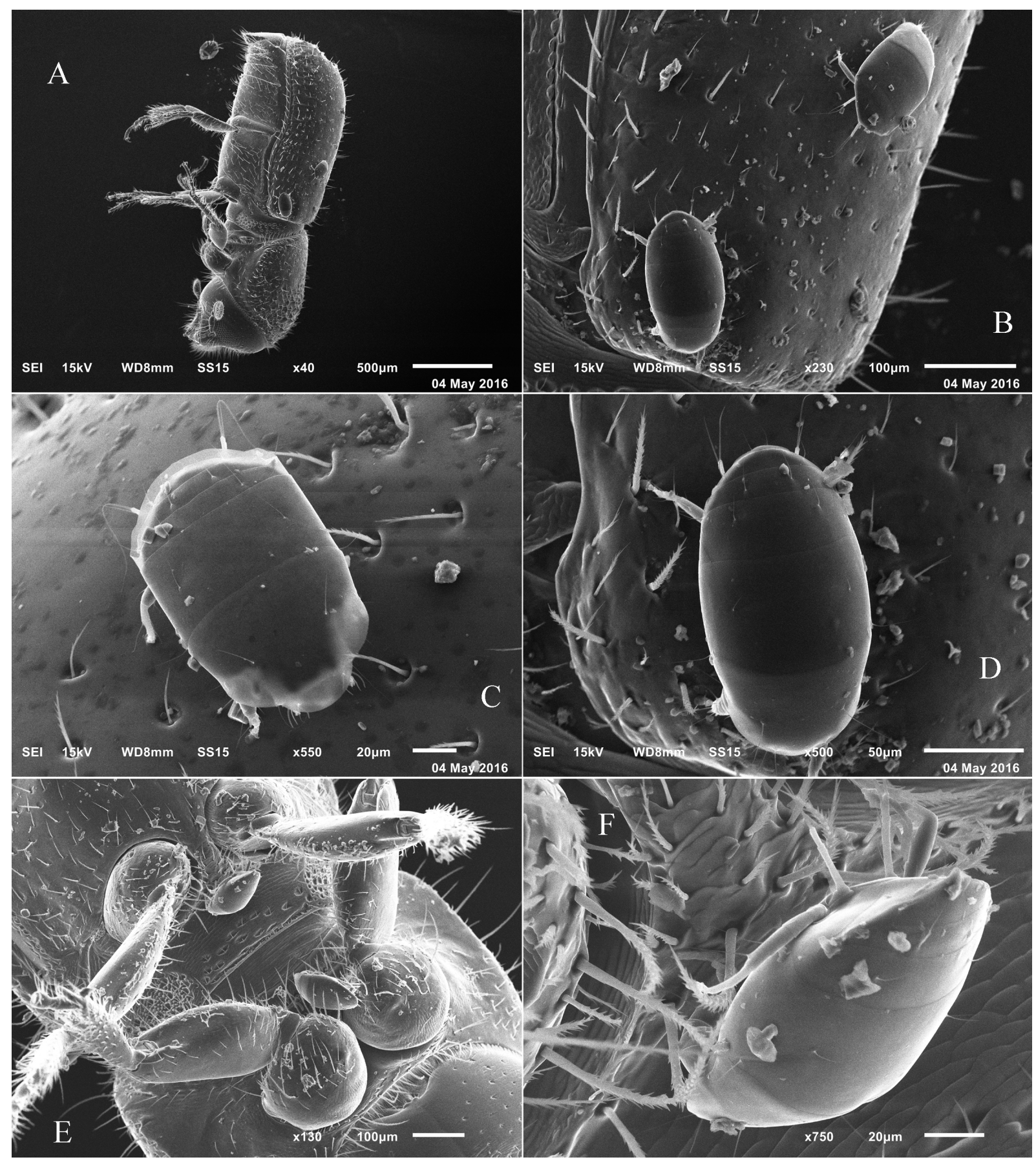

Fig. 7. SEM photographs. Phoresy of females of Tarsonemus (Schaarschmidtia) bistridentati Magowski and Khaustov, 2006 on Pityogenes chalcographus: A-D—on elytra, E-F_-between coxae I and II.

were dominant and together represented $90 \%$ of all collected mites. Other mite species were collected in lower numbers.

Some species had specific sites for the phoretic attachment to the bark beetle body. Deutonymphs of Trichouropoda polytricha mainly attached to the abdomen and the area between the legs of the beetle. More rarely, they attached to the elytra and the dorsal thorax. Females of Pyemotes dryas always attach between coxae I and II of the beetle as well as fe- males of Tarsonemus bistridentati. Sometimes females of $T$. bistridentati could attach to the elytra or the dorsal thorax of the beetle. Females and males of Pleuronectocelaeno barbara, females of Proctolaelaps fiseri and deutonymphs of Schizosthetus simulatrix $\mathrm{sp}$. were observed actively moving around the beetle body.

Usually, most of the phoretic mite species were represented by only a single individual per beetle. But up to 11 individual deutonymphs of Trichouropoda 


\section{A. A. Khaustov, V. A. Trach and A. N. Bobylev}

polytricha sometimes attached themselves to beetle, and up to 6 females of Tarsonemus bistridentati per beetle (Table 1).

\section{Hyperphoresy of deutonymphs of Trichouropoda polytricha and Histiostoma piceae}

Hyperphoresy (superphoresy or phoresy of the second order) describes a situation, in which an animal is phoretically transported by an insect, but carries additionally another phoretic animal itself (Chmielewski 1977; Davydova 1978; Bajerlein and Błoszyk 2003). During this study, we revealed one case of hyperphoresy of a deutonymph of Trichouropoda polytricha on a female of Pleuronectocelaeno barbara. The deutonymph of T. polytricha was attached to the dorsal shield of P. barbara (Figs. 4E-F).

Hyperphoresy in mites of the Histiostomatidae is only barely studied, but might be rather common under suitable conditions. Samplings are often performed via pheromone traps, which is why mite behaviors inside the bark beetle galleries often remain undiscovered. Wirth et al. (2015) observed that deutonymphs of Histiostoma ovalis often attached to Dendrolaelaps sp., while these gamasids were carried phoretically by Ips sexdentatus inside their elytral declivities.

Reports about the hyperphoretic behavior of $H$. piceae were missing so far. Inside the original bark samples of this study, the deutonymphs were discovered on the uropodids Uroobovella ipidis (Fig. 3E) and Trichouropoda sp. (Fig. 3F) inside the beetle galleries. Three deutonymphs were found attached to a phoretic deutonymph of $U$. ipidis being fixed to a beetle specimen of $P$. chalcographus (Figs. 3C, D). This represents the only case of hyperphoresy with histiostomatid deutonymphs in our samples.

Inside the gallery samples, $H$. piceae attached to an unexpected multitude of arthropods. They appeared besides $P$. chalcographus, the oribatid Siculobata (Paraleius) leontonycha (Figs. 5A-D) and the two uropodid species. Ips typographus galleries and beetles were found close to the galleries of P. chalcographus. As I. typographus is still known as the most common phoretic carrier for H. piceae (Scheucher 1957; Wirth et al. 2016), it is assumed that $H$. piceae deutonymphs originally arrived with I. typographus and subsequently attached to other arthropods that were available nearby.

\section{ACKNOWLEDGEMENTS}

The authors thank Dr. Sergey Ermilov and Dr. S. F. Wirth, both from Tyumen State University, Russia, for the identification of the oribatid mites; and histiostomatid mites correspondingly and valuable comments; and Massimo Plumari (Fondazione IRCCS, Istituto Neurologico Carlo Besta, Milan, Italy) for the information about the morphology of Sch. simulatrix from Italy. The present research was supported by the grant from the Russian Science Foundation, project No. 16-14-10109 to Dr. A. A. Khaustov.

\section{REFERENCES}

Al-Atawi, F., Klompen, H., and Moser, J. C. 2002. Redescription of Schizosthetus lyriformis (McGraw and Farrier, 1969) (Parasitiformes: Parasitidae), with revision of the genus. International Journal of Acarology, 28: 341-360.

Ahadiyat, A. and Akrami, M. A. 2015. Oribatid mites (Acari: Oribatida) associated with bark beetles (Coleoptera: Curculionidae: Scolytinae) in Iran, with a review on Paraleius leontonychus (Berlese) and a list of bark beetles in association with this species. Persian Journal of Acarology, 4: 355-371.

Ahadiyat, A., Ostovan, H., Gwiazdowicz, D. J., and Valizadeh, A. 2012. Celaenopsid mites (Mesostigmata) associated with the Mediterranean pine engraver beetle, Orthotomicus erosus (Wollaston) (Coleoptera: Curculionidae: Scolytinae), in Iran. In: A. Sarafrazi, M. R. Asef, M. Mozhdehi, M. Mozhdehi, S. S. Fard, and T. Abdollahi (Eds.). Proceedings of the $20^{\text {th }}$ Iranian Plant Protection Congress. 26-29 August. Shiraz University, Iran, p. 475

Athias-Henriot, C. 1959. Contribution aux genres Podocinum Berlese et Pleuronectocelaeno Vitzthum en Algerie et remarques sur les genres Aceosejus Sellnick et Seiodes Berlese (Mesostigmata). Acarologia, 1: 24-38.

Athias-Henriot, C. 1982. Schizosthetus n. g. (type Eugamasw lyrifonnis McGr. and Farr., 1969) avec deux espèces nouvelles (Parasitiformes, Parasitidae). Acarologia, 23: 207-214.

Bajerlein, D. and Błoszyk, J. 2003. Two cases of hyperphoresy in mesostigmatic mites (Acari: Gamasida: Uropodidae, Macrochelidae). Biological Letters, 40, 135-136.

Feketesová, Z. 2011. Výzmam uropodných roztočov (Acari: Uropodina) v ekológii lyrožrúta smrekového (Ips typographus). Entomofauna Carpathica, 23: 11-19. 
Čejka, M. and Holuša, J. 2014. Phoretic mites in uniand bivoltine populations of Ips typographus: a 1-year case study. Turkish Journal of Zoology, 38: 569-574.

Chaires-Grijalva, M. P., Estrada-Venegas, E. J., Equihua-Martínez, A., Moser, J. C., Sánchez-Martínez, G., Vázquez-Rojas, I. M., Otero-Colina, G., and Romero-Nápoles, J. 2013. Mesostigmados (Acari: Mesostigmata) asociados con Dendroctonus rhizophagus de Chihuahua, México. Revista Mexicana de Biodiversidad, 84: 1235-1242.

Chmielewski, W. 1977. Wyniki obserwacji powązań roztoczy z owadami (Acari-Insecta). Polskie Pismo Entomologiczne, 47: 59-78.

Davydova, M. S. 1978. [Osobennosti raspredeleniya svobodnozyvuschich gamasovyh kleschey po landshaftam i nekotorym microbiotopam]. In: G. S. Zolotarenko (Ed). Arthropods of Siberia. Novosibirsk: Nauka: 32-38. [In Russian]

Davydova, M. S. and Nikolsky, V. V. 1986. [Gamasid mites of West Siberia]. Novosibirsk: Nauka, 123 pp. [In Russian]

Gwiazdowicz, D. J. 2008. Mesostigmatid mites (Acari) associated with Scolytidae in Poland. In: D. J. Gwiazdowicz (Ed.). Selected problems of acarological redearch in forests. Poznan: Wydawnictwo Uniwersytetu Przyrodniczego: 59-95.

Gwiazdowicz, D. J. and Gutowski, J. M. Records of phoretic mesostigmatid mites (Acari: Mesostigmata) on beetles (Coleoptera: Carabidae, Cerambycidae, Elateridae, Erotylidae, Scolytinae) in the Białowieża Primeval Forest. Polskie Pismo Entomologiczne, 81: 305-310.

Gwiazdowicz, D. J., Kamczyc, J., and Błoszyk, J. 2011. The diversity of phoretic Mesostigmata on Ips typographus (Coleoptera: Scolytinae) caught in the Karkonosze forest. European Journal of Entomology, 108: 489-491.

Gwiazdowicz, D. J., Kamczyc, J., Teodorowicz, E., and Błoszyk, J. 2012. Mite communities (Acari, Mesostigmata) associated with Ips typographus (Coleoptera, Scolytidae) in managed and natural Norway spruce stands in Central Europe. Central European Journal of Biology, 7: 910-916.

Hirschmann, W. and Wioeniewski, J. 1982. Weltweite revision der Gattungen Dendrolaelaps Halbert 1915 und Longoseius Chant 1961 (Parasitiformes). Band II. Acarologie, 29: 1-48, 1-94 pl.

Hofstetter, R. W., Dinkins-Bookwalter, J., Davis, T. S., and Klepzig, K. D. 2015. Symbiotic associations of bark beetles. In: F. E. Vega and R. W. Hofstetter. Bark Beetles, Biology and Ecology of Native and Invasive species. $1^{\text {st }}$ ed. Elsevier Academic Press, pp. 209-245.
Hofstetter, R. W., Moser, J. C., and McGuire, R. 2009. Observations on the mite Schizosthetus lyriformis (Acari: Parasitidae) preying on bark beetle eggs and larvae. Entomological News, 120: 397-400.

Kalúz, S., Mašán, P., and Moser, J. C. 2003. Morphology and ecology of Schizosthetus simulatrix (Acari, Mesostigmata) associated with galleries of bark beetles (Scolytidae). Biologia, 58: 165-172.

Khaustov, A. A. 1997. [Mites of supercohort Trigynaspida (Parasitiformes. Celaenopsidae, Cercomegistidae) associated with bark beetles (Coleoptera, Scolytidae) of Crimea]. Bulletin of the State Nikitsky Botanical Gardens, 78: 63-66. [In Russian]

Khaustov, A. A. 1998. [Mites of the genus Pyemotes (Acariformes, Pyemotidae) associated with bark beetles (Coleoptera, Scolytidae) in Crimea]. Zoologicheskiy Zhurnal, 77: 1419-1424. [In Russian]

Khaustov, A. A. 2001. [New and little known species of the genus Heterotarsonemus (Acarina, Heterostigmata, Tarsonemidae) from Crimea]. Vestnik Zoologii, 35: 81-84. [In Russian]

Kiełczewski, B., Moser J. C., and Wiśniewski, J. 1983. Surveying the acarofauna associated with Polish Scolytidae. Bulletin de la Société des amis des sciences et des lettres de Poznań, Serie D, 22: 151-159.

Kielczewski, B. and Wisniewski, J. 1980. Bark beetle acarofauna in different types of forest habitat. Part III. Tarsonemini, Prostigmata, Acaridiae. Bulletin de la Societe des Amis des Sciences et des Lettres de Poznan, Series D, Sciences Biologiques, 20: 161-175.

Kielczewski, B. and Wisniewski, J. 1983. Bark beetle acarofauna in different types of forest habitat. Part I and II. Introduction and Mesostigmata. Folia Forestalia Polonica, Seria A, 25: 129-162.

Kinn, D. N. 1968. A new species of Pleuronectocelaeno (Acarina: Celaenopsidae) associated with bark beetles in North and Central America. Acarologia, 10: 191-205.

Kinn, D. N. 1976. Key to mites commonly associated with the southern pine beetle. Southern Forest Experiment Station Research, Note SO-214: 1-11.

Kinn, D. N. 1991. A new Pleuronectocelaeno (Acari: Celaenopsidae) from Japan, with remarks on North American and European species. International Journal of Acarology, 17: 103-105.

Knee, W., Forbes, M. R., and Beaulieu, F. 2013. Diversity and host use of mites (Acari: Mesostigmata, Oribatida) phoretic on bark beetles (Coleoptera: Scolytinae): global generalists, local specialists? Annals of the Entomological Society of America, 106: 339-350. 
Kofler, A. and Schmölzer, K. 2000. Zur Kenntnis phoretischer Milben und ihrer Tragwirte in Österreich (Acarina: Gamasina, Uropodina). Berichte des Naturwissenschaftlich Medicinischen Vereins in Innsbruck, 87: 133-157.

Kršlak, B., Zach, P., and Kulfan J. 2010. The role of Hylastes cunicularius Erichson (Coleoptera: Scolytidae) in transferring uropodine mites in a mountain spruce forest. Journal of Forest Science, 56: 258-264.

Lieutier, F. 1978. Les acariens associes a Ips typographus et Ips sexdentatus (Coleoptera: Scolytidae) en region parisienne et les variations de leurs populations au cours du cycle annuel. Bulletin d'Ecologie, 9: 307-321.

Lindquist, E. E. 1970. Relationships between mites and insects in forest habitats. Canadian Entomologist, 102: 978-984.

Lindquist, E. E. and Hunter, P. E. 1965. Some mites of the genus Proctolaelaps Berlese (Acarina: Blattisociidae) associated with forest insect pests. $\mathrm{Ca}$ nadian Entomologist, 97: 16-32.

Magowski, W. Ł. 2010. Schaarschmidtia, a new subgenus of the genus Tarsonemus Canestrini \& Fanzago, 1876 (Acari: Heterostigmatina: Tarsonemidae) - a systematic review of the mite taxon associated with subcortical coleopteran insects, with notes on its host affiliation, ecology and biogeography. Polish Journal of Entomology, 79: Supplement, 176 pp.

Magowski, W. L. and Khaustov, A. A. 2006. Two new species of Tarsonemus (Acari: Tarsonemidae) associated with bark beetles (Coleoptera: Scolytidae) from Crimea, Ukraine. Zootaxa, 1359: 31-55.

Mašán, P. 2001. Roztoče kohorty Uropodina (Acarina, Mesostigmata) Slovenska (Mites of the cohort Uropodina (Acarina, Mesostigmata) in Slovakia. Annotationes Zoologicae et Botanicae, 22: 1-320.

Maslov, A. D. and Matusevich, L. S. 2008. Rol'kleschey (Acari) v populacionnoy dinamike koroedov (Coleoptera, Scolytidae) [Mites' (Acari) role in the population dynamics of bark beetles (Coleoptera, Scolytidae)]. Lesnoy Vestnik, 1, 66-72. [In Russian]

Moraza, M. L., Fernández, M., and Jurc, M. 2013. Phoretic mites of the six-spined engraver beetle, Ips sexdentatus (Böerner, 1776) (Coleoptera, Scolytinae), on Pinus halepensis in Slovenia. International Journal of Acarology, 39: 597-599.

Moser, J. C. and Bogenschütz, H. 1984. A key to the mites associated with flying Ips typographus in South Germany. Zeitschrift für Entomologie, 97: 437-450.

Moser, J. C., Eidmann, H. H., and Regnander, J. R. 1989. The mites associated with Ips typographus in Sweden. Annales Entomologici Fennici, 55: 23-27.
Moser, J. C., Kiełczewski, B., Wiśniewski, J., and Bałazy, S. 1978. Evaluating Pyemotes dryas (Vitzthum, 1923) as a parasite of the Southern pine beetle. International Journal of Acarology, 4: 67-70.

Moser, J. C., Konrad, H., Kirisits, T., and Carta, L. K. 2005. Phoretic mites and nematode associates of Scolytus multistriatus and Scolytus pygmaeus (Coleoptera: Scolytidae) in Austria. Agricultural and Forest Entomology, 7: 169-177.

Moser, J. C., Perry, T. J., and Furuta, K. 1997. Phoretic mites and their hyperphoretic fungi associated with flying Ips typographus japonicus Niijima (Col., Scolytidae) in Japan. Journal of Applied Entomology, 121: 425-428.

Moser, J. C. and Roton, L. M. 1971. Mites associated with Southern Pine Bark Beetles in Allen Parish, Louisiana. The Canadian Entomologist, 103: 1775-1798.

Penttinen, R., Viiri, H., and Moser, J. C. 2013. The mites (Acari) associated with bark beetles in the Koli National Park in Finland. Acarologia, 53: 3-15.

Pernek, M., Hrasovec, B., Matosevic, D., Pilas, I., Kirisits, T., and Moser, J. C. 2008. Phoretic mites of three bark beetles (Pityocteines spp.) on Silver fir. Journal of Pest Science, 81: 35-42.

Pernek, M., Wirth, S., Blomquist S. R., Avtzis, D. N., and Moser, J. C. 2012. New associations of phoretic mites on Pityocteines curvidens (Coleoptera, Curculionidae, Scolytinae). Central European Journal of Biology, 7: 63-68.

Plumari, M. 2008. Specie di Celaenopsidae, Parasitidae, Digamasellidae e Ascidae nuove per l'Italia (Acarina Mesostigmata). Bolletino della Societa Entomologica Italiana, 140: 75-90.

Salmane, I. and Telnov, D. 2009. Mesostigmata mites (Acari: Parasitiformes) associated with beetles (Insecta: Coleoptera) in Latvia. Latvijas Entomologs, 47: 58-70.

Schaarschmidt, L. 1959. Systematik und Ökologie der Tarsonemiden. Beiträge zur Systematik und Ökologie mitteleuropäischer Acarina, 1, 713-823.

Scheucher, R. 1957. Systematik und Ökologie der deutschen Anoetinen. Beiträge zur Systematik und Ökologie mitteleuropäischer Acarina, 1, 233-384.

Sellnick, M. 1951. Pleuronectocelaeno austriaca (Vitzthum) und P. africana n. sp. (Acarini). Entomologisk Tidskrift, 72: 189-194.

Stephen, F. M. and Kinn, D. N. 1980. Spatial distribution of mite associates of within-tree populations of Dendroctonus frontalis Zimm. Environmental Entomology, 9: 13-15.

Tikhomirov, S. I. 1977. Sem. Parasitidae Oudemans, 1901. In: N. G. Bregetova, B. A. Vainstein, B. A. Kadite, E. V. Koroleva, A. D. Petrova, S. I. Tikhomirov, and 
G. L. Shcherbak (Eds). Opredelitel' obitayushchikh v pochve kleshchei-Mesostigmata. Nauka [Determinant for mites (Mesostigmata) living in soil], Leningrad, pp. 55-107. [In Russian]

Vitzthum, H. G. 1923. Acarologische Beobachtungen 7 Reihe. Archiv für Naturgeschichte, Abteilung A, 89: 97-181.

Vrabec, M., Kaluz, S., and Ferenčik, J. 2012. Foretické roztoče na lykožrútovi smrekovom (Ips typographus) na vybraných lokalitách vo Vysokých Tatrách. Entomofauna Carpathica, 24: 1-14.

Westerboer, I. 1963. Die Familie Podocinidae Berlese 1916. In: H.-J. Stammer (Ed.). Beiträge zur Systematik und Ökologie Mitteleuropäischer Acarina. Band II. Mesostigmata I. Akademische Verlagsgesellschaft Geest \& Portig K.-G., Leipzig, pp. 179-450.

Wirth, S. F. 2004: Phylogeny, biology and character transformations of the Histiostomatidae (Acari,
Astigmata). Promotionsarbeit. http://www.diss. fu-berlin.de/2004/312

Wirth, S. F. and Garonna, A. P. 2015. Histiostoma ovalis (Histiostomatidae, Acari) associated with Ips sexdentatus (Scolytinae, Curculionidae, Coleoptera): ecology and mite redescription on the basis of formerly unknown adults and nymphs. International Journal of Acarology, 41: 415-428.

Wirth, S. F., Weis, O., and Pernek M. 2016. A comparison of phoretic mites associated with bark beetles Ips typographus and Ips cembrae from Central Croatia. Šumarski List, 11-12: 561-572.

Zach, P., Kršiak, B., Kulfan J., Parák, M., and Kontschán, J. 2016. Mites Trichouropoda and Uroobovella spp. (Uropodoidea) phoretic on bark beetles (Scolytinae): a comparison from a declining mountain spruce forest in Central Europe. International Journal of Acarology, 42: 212-217.

Table 1.

Species spectrum and abundance of mites phoretic on Pityogenes chalcographus in Western Siberia

\begin{tabular}{|c|c|c|c|c|}
\hline Mite species and phoretic stage & Location on beetle & $\begin{array}{c}\text { Total number } \\
\text { of phoretic } \\
\text { mites }\end{array}$ & $\begin{array}{c}\text { Maximum number } \\
\text { of phoretic mites } \\
\text { per one beetle }\end{array}$ & $\begin{array}{l}\text { Percent of total } \\
\text { mites found } \\
(\mathrm{n}=651)\end{array}$ \\
\hline $\begin{array}{l}\text { Trichouropoda polytricha } \\
\text { Deutonymph }\end{array}$ & $\begin{array}{l}\text { Mainly at abdomen, } \\
\text { between legs }\end{array}$ & 421 & 11 & 64.66 \\
\hline $\begin{array}{l}\text { Uroobovella ipidis } \\
\text { Deutonymph }\end{array}$ & $\begin{array}{l}\text { Elytral declivity, } \\
\text { thorax }\end{array}$ & 3 & 1 & 0.46 \\
\hline $\begin{array}{l}\text { Pleuronectocelaeno barbara } \\
\text { Female, male }\end{array}$ & All body & 15 & 1 & 2.30 \\
\hline $\begin{array}{l}\text { Schizosthetus sp. } \\
\text { Deutonymph }\end{array}$ & All body & 6 & 1 & 0.92 \\
\hline $\begin{array}{l}\text { Dendrolaelaps quadrisetosimilis } \\
\text { Deutonymph }\end{array}$ & All body & 2 & 1 & 0.30 \\
\hline $\begin{array}{l}\text { Proctolaelaps fiseri } \\
\text { Female }\end{array}$ & All body & 9 & 1 & 1.38 \\
\hline $\begin{array}{l}\text { Siculobata (Paraleius) leontonycha } \\
\text { Female }\end{array}$ & Unknown & 1 & 1 & 0.15 \\
\hline $\begin{array}{l}\text { Histiostoma piceae } \\
\text { Deutonymph }\end{array}$ & All body & 15 & 3 & 2.30 \\
\hline $\begin{array}{l}\text { Pyemotes dryas } \\
\text { Female }\end{array}$ & $\begin{array}{c}\text { Between coxae of legs } \\
\text { I and II }\end{array}$ & 8 & 2 & 1.22 \\
\hline $\begin{array}{l}\text { Heterotarsonemus coleopterorum } \\
\text { Female }\end{array}$ & Unknown & 3 & 1 & 0.46 \\
\hline $\begin{array}{l}\text { Tarsonemus bistridentati } \\
\text { Female }\end{array}$ & $\begin{array}{c}\text { Between coxae of legs } \\
\text { I and II, rarely on other } \\
\text { parts of the body }\end{array}$ & 168 & 6 & 25.80 \\
\hline
\end{tabular}


